\title{
Measurement Science Roadmap Workshop for Water Use Efficiency and Water Quality in Premise Plumbing Systems: August 1-2, 2018
}

Synthesis of a Workshop organized by the National Institute of Standards and Technology, U.S. Environmental Protection Agency, and Water Research Foundation

Eastern Research Group, Inc. (ERG): Robert Pickering Kathleen Onorevole Ross Strategic: Rob Greenwood Sarah Shadid 
NIST GCR 19-020

\section{Measurement Science Roadmap Workshop for Water Use Efficiency and Water Quality in Premise Plumbing Systems: August 1-2, 2018}

Synthesis of a Workshop organized by the National Institute of Standards and Technology, U.S. Environmental Protection Agency, and Water Research Foundation

Prepared for

U.S. Department of Commerce

Engineering Laboratory

National Institute of Standards and

Technology

Gaithersburg, MD 20899
WaterSense

Office of Wastewater Management U.S. Environmental Protection Agency

Washington, D.C. 20460

By

Robert Pickering

Kathleen Onorevole

Rob Greenwood

Sarah Shadid

Eastern Research Group, Inc. (ERG)

This publication is available free of charge from: https://doi.org/10.6028/NIST.GCR.19-020

December 2018

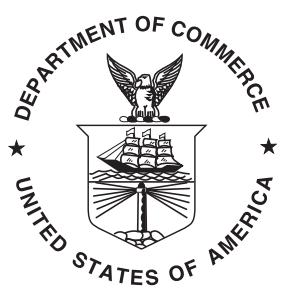

U.S. Department of Commerce Wilbur L. Ross, Jr., Secretary

National Institute of Standards and Technology Walter Copan, NIST Director and Undersecretary of Commerce for Standards and Technology 


\section{Disclaimer}

This publication was produced as part of an interagency agreement (EPA: RW-013-924975010, NIST: P18-732-0001) between the National Institute of Standards and Technology and the U.S. Environmental Protection Agency. The contents of this publication do not necessarily reflect the views or policies of the National Institute of Standards and Technology, the U.S. Environmental Protection Agency, or the US Government. 


\title{
Measurement Science Roadmap Workshop for Water Use Efficiency and Water Quality in Premise Plumbing Systems
}

\author{
August 1-2, 2018 \\ Synthesis of a Workshop \\ organized by the
}

National Institute of Standards and Technology

U.S. Environmental Protection Agency

Water Research Foundation 
Acknowledgments

The Measurement Science Roadmap Workshop for Water Use Efficiency and Water Quality in Premise Plumbing Systems and this synthesis document were developed through an interagency agreement between the U.S. Environmental Protection Agency (EPA) WaterSense program and the National Institute of Standards and Technology (NIST).

Workshop Steering Committee

NIST: Andrew Persily, Tania Ullah, David Yashar

U.S. EPA WaterSense: Veronica Blette, Stephanie Tanner

Water Research Foundation (WRF): Maureen Hodgins, H. Grace Jang, Beate Wright

Contract Team

Eastern Research Group, Inc. (ERG): Robert Pickering, Kathleen Onorevole

Ross Strategic: Rob Greenwood, Sarah Shadid 


\section{Table of Contents}

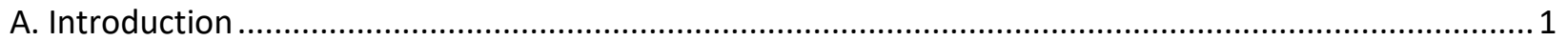

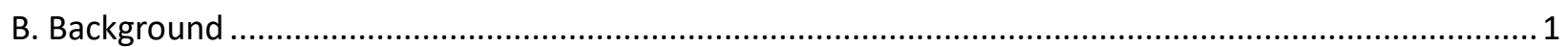

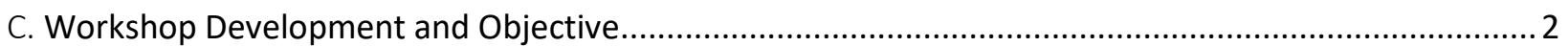

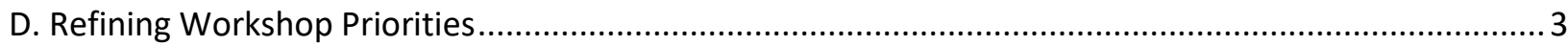

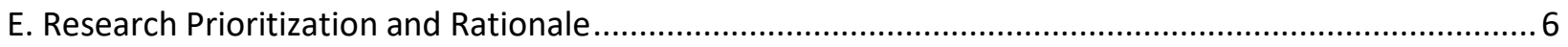

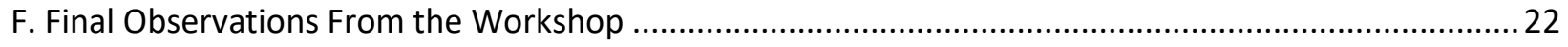

G. Future Work

Appendix A: Premise Plumbing Workshop Agenda, August 1-2, 2018 ........................................... A-1

Appendix B: Premise Plumbing Workshop Attendees...........................................................................

Appendix C: Premise Plumbing Workshop References ........................................................................ 
This page intentionally left blank 


\section{A. Introduction}

In August 2018, the National Institute of Standards and Technology (NIST), the U.S. Environmental Protection Agency (EPA) WaterSense program, and the Water Research Foundation (WRF) organized a Measurement Science Roadmap Workshop for Water Use Efficiency and Water Quality in Premise Plumbing Systems (hereafter referred to as the Premise Plumbing Workshop) with representatives from industry, academia, government, utilities, standards and codes organizations, and other research and stakeholder organizations. The intent of the workshop was to identify and organize measurement science research needed to improve the efficiency and quality of water delivered by premise plumbing systems. The workshop results, along with feedback from stakeholder engagement efforts, will form the basis for potential future program development within multiple public and private sector agencies and organizations.

\section{B. Background}

Premise plumbing systems are critical to the built environment, given that our ability to live and thrive in buildings is highly dependent on reliable, efficient, and sustainable access to potable water. The design of premise plumbing systems in the United States is based in part on decades-old data embodied in building codes, much of which was developed at NIST. However, many important factors affecting these systems have changed considerably in recent years. Namely, there has been widespread adoption of high-efficiency plumbing fixtures and appliances, resulting in declining per capita water demand in the United States. This can create flow conditions within plumbing systems that are different from what they were designed to accommodate, which may be contributing to conditions conducive to increased potential for human exposure to opportunistic premise plumbing pathogens (OPPPs) and other water quality issues. New technical research and data are needed to ensure that premise plumbing systems are designed, installed, and operated such that the goals of water and energy efficiency and water quality are considered in an integrated manner, based in part on the following considerations:

- Population growth and concerns regarding the scarcity of water and the ability to deliver potable water through an aging infrastructure have led Americans to implement measures that have reduced indoor household water use by 22 percent since the late $1990 \mathrm{~s}^{1}$, with much of this reduction stemming from the national efficiency standards for plumbing fixtures and appliances that were included in the Energy Policy Act (EPAct) of 1992. As a result, new premise plumbing systems are being designed and installed with water flow rates that are significantly lower than those corresponding to the design data in building codes and other guidance.

- Many existing plumbing systems are being operated at lower flow rates than those for which they were designed to operate. These lower flow rates create situations where water remains in distribution and building plumbing systems for longer periods of time, potentially reducing protective disinfectant residual concentrations and leading to conditions that can promote the growth of opportunistic waterborne pathogens.

- Materials used in piping networks and fixtures have changed, and there is insufficient information about their performance and impacts over time.

\footnotetext{
${ }^{1}$ The Water Research Foundation, 2016. Residential End Uses of Water, Version 2. www.waterrf.org/Pages/Projects.aspx?PID=4309
} 
- Water-stressed areas are considering water reuse for a variety of potable and non-potable uses. However, there is some uncertainty regarding distribution and conveyance design criteria to deliver water in a healthy and sustainable manner.

- The distribution and consumption of water inside a building has a significant influence on the amount of energy that a building consumes. Efforts to advance energy efficiency may affect how water moves in a building, as well as its resulting water quality.

- The need to use water more efficiently to supply a growing population and economy will become more pressing as water shortages, most notably in the western United States, become more frequent and/or severe. The U.S. Government Accountability Office predicts that water shortages in non-drought conditions will be experienced in 40 states by $2024^{2}$.

Based on these factors and trends, it is clear that research is needed to advance the state of knowledge that supports the design of new premise plumbing systems and the operation and retrofit of existing systems to help protect public health, conserve water resources, and support resilience.

\section{Workshop Development and Objective}

The workshop objective was to identify and discuss research needs to support the design and operation of new premise plumbing systems and the management of existing systems in light of lower water consumption and the need to ensure water quality at the point of use. The research needs identified as part of the workshop will be incorporated into long-term research planning that can be used by multiple parties to advance water use efficiency and water quality in buildings. As part of these follow-up efforts, NIST will consider the output of this workshop, along with other information, to develop a premise plumbing research roadmap.

The workshop steering committee initially proposed that the workshop address the following issues:

- The need for updated data and models to support the design of new premise plumbing systems based on lower water flow rates, piping system material choices (including new materials), and increased awareness of opportunistic pathogens and other water quality issues. These data and models are expected to be implemented through updated design practice and building codes and standards.

- The need for new information to inform the operation and potential retrofit of existing plumbing systems that are subject to lower water flow rates than those for which they were designed and that are affected by aging or antiquated plumbing materials.

- The design of future plumbing systems that account for factors such as increasing demands for water and energy efficiency without compromising water quality, technologies such as onsite reuse, and different scales of delivery and treatment (from single buildings to campuses).

- The impact of human factors such as design, usage patterns, wealth, and locality as they influence water use, system operation, and maintenance. Design also includes retrofit and expansion projects, which can affect water quality and system operation.

\footnotetext{
2 U.S. Government Accountability Office, 2014. Freshwater: Supply Concerns Continue, and Uncertainties Complicate Planning. May 22, 2014. www.gao.gov/products/GAO-14-430
} 
To make the best use of time during the in-person meeting, participants were asked to provide input prior to the workshop, including their perspective on the appropriate focus of the workshop. This information helped the steering committee modify and refine the focus ahead of the workshop and identify issues to address during the session. This refinement and the updated core issues are discussed in more detail in Section D.

For the purposes of this workshop synthesis, premise plumbing is defined as all potable and non-potable piping and appurtenances delivering water to point of use (e.g., plumbing fixtures, water heaters, chillers) as well as conveying water discharged as part of waste stream within a building, and includes reuse, collection systems, and onsite storage in a residential or commercial facility. In terms of scope, the workshop discussion considered the following aspects and features of premise plumbing systems:

- All premise plumbing systems in residential, commercial and industrial buildings, per the above definition, including but not limited to irrigation systems, fire suppression systems, cooling towers, water features, and data centers;

- Materials used in plumbing systems, their resistance to corrosion, their ability to maintain structural integrity, and their interaction with contaminants and treatment chemicals;

- The physical attributes of the plumbing system, including pipe diameter, length, and the presence of features that result in stagnation, such as dead-legs. ${ }^{3}$

- System operation and maintenance and occupant water use;

- Water quality conditions at point of entry into the building and the change in the quality of water before its on-site point of use; and

- Data needed for design and operation, including water demand assumptions.

Appendix A includes the full workshop agenda, which lists the introductory speakers and has details of the workshop breakout sessions used to articulate and prioritize research needs for designing, operating, and managing premise plumbing systems to ensure water efficiency and water quality at point of use.

Workshop participants included representatives from industry, academia, government, utilities, standards and codes organizations, and other research and stakeholder organizations, and they provided their perspectives based on their expertise on concerns and research needs related to premise plumbing. Appendix B includes a list of workshop participants.

\section{Refining Workshop Priorities}

Before the workshop, NIST, EPA, and WRF contacted the participants to obtain their perspective on the proposed scope and objectives to help identify common themes and issues that workshop participants wanted to prioritize over the two-day workshop. Participants were asked to respond to five questions:

1. Do you have any feedback on the core issues and scope identified in the two-page background document that was sent with the original invitation?

\footnotetext{
${ }^{3} \mathrm{~A}$ dead-leg, also known as a dead-end, is a section of potable water piping or plumbing that has been altered, abandoned, or capped such that water no longer flows through it. Extended period of no flow through temporary or permanent dead-legs can lead to water stagnation. (Source: Occupational Safety and Health Administration (OSHA) Technical Manual, Section III, Chapter 7.)
} 
2. What do you see as the three most important drivers that are impacting the design and operation of premise plumbing systems?

3. Are there specific areas where you believe current data, modeling tools, standards/codes, and guidance materials are lacking in their ability to support the design and operation of premise plumbing systems?

4. What you see as the three most important research needs to support the design and operation of premise plumbing systems?

5. Do you know of any key resources that would inform development of a research agenda?

Approximately 30 participants provided input, which is summarized below.

Suggested Scope Inclusions

Most participants agreed with the core issues and research objectives identified in the two-page background document distributed ahead of the workshop. Some participants suggested expanding the scope of the workshop to address more issues, including:

- Impacts to wastewater systems

- Hot water distribution system design

- Impacts of operating with energy efficiency as a goal

- Impacts of home size and layout

- Plumbing fixture materials and technologies

- Temporary and permanent dead-legs

- Identifying the "shelf life" of water

- Appropriate test methods to efficiently and effectively monitor water quality

- Efficacy of point-of-entry and point-of-use water treatment systems

- Impacts of onsite reuse systems

- Existing building water management planning and implementation

- Education and training resources

\section{Drivers Impacting Premise Plumbing Systems}

Pre-workshop input also included drivers that impact the design and function of premise plumbing systems. Feedback identified several common drivers, including outdated codes and standards, water efficiency and low-flow plumbing fixtures, and energy efficiency. Participants observed that although there is demand for greater water and energy efficiency in the built environment, codes and standards have not been updated to account for lower flow rates and operational changes.

Another consensus driver is that building and plumbing system design impacts a system's ability to provide high-quality water efficiently. Premise plumbing systems may be greatly oversized to meet the demands for potable water service, in the face of decreasing water demand and incorporation of non-potable water sources in building design. Similarly, decreases in water use may create challenges for water distribution and sewer pipes designed to accommodate greater flows.

The push to reduce design, material, and building costs was also seen by participants as a driver for some unforeseen consequences in the premise plumbing systems and suggested that while certain plumbing materials may be less expensive and more flexible, the use of these materials could impact water quality.

Participants also identified other drivers that impact premise plumbing systems. 
- There has been an increase in incidents and outbreaks related to OPPPs in recent years, resulting in more attention to disease prevention and water quality in buildings.

- The United States has aging water and wastewater infrastructure that is in need of reinvestment and renewal. At the same time, an aging building stock exists and continues to grow. Legacy issues persist from old plumbing system materials and new issues continue to arise as water use behavior and operation and maintenance recommendations change.

- Differences in source water create differences in water quality and biological characteristics. For example, some regions are beginning to depend more on surface water, which has different biological characteristics than groundwater.

- Material, design, and installation preferences of architects, plumbing designers, home builders, plumbers and contractors may impact systems operation. These professionals are continuing to use older techniques, perpetuating poor plumbing design, installation, and operation.

- The designer, builder, and end-user communities do not necessarily have the resources and tools to fully understand premise plumbing issues.

\section{Core Research Topics}

The remaining questions from the pre-workshop information request focused on research items that participants thought were necessary to understand and address premise plumbing concerns. The workshop steering committee identified 30 unique research items among 80 responses and prioritized them based on the frequency of submission. Four core research themes emerged from this effort:

- Research Area 1: Water usage patterns and end uses in commercial and residential plumbing as they relate to system design and pipe sizing

- Research Area 2: Impacts of pipe material and installation on the long-term condition of the plumbing system

- Research Area 3: Impact of water use/flow rate/water velocity on water quality and biofilm growth

- Research Area 4: Efficacy of water management and/or treatment strategies for maintaining water quality

The responses to the pre-workshop information request indicated high interest in topics related to Research Area 1. As a result, the steering committee dedicated two rounds of the breakout session during the workshop to addressing this research area to ensure all interested attendees could participate in the discussion.

Although Research Area 4 was identified as a core theme, WRF and EPA are already undertaking research that seeks to address certain research items related to this topic., ${ }^{4,6}$ Therefore, the steering committee decided to focus on the workshop discussion around the first three research areas.

\footnotetext{
${ }^{4}$ WRF. Waterborne pathogens in distribution and premise plumbing systems. www.waterrf.org/thefoundation/research-programs/focus-area-program/Pages/waterborne-pathogens.aspx

${ }^{5}$ WRF. Water demand. www.waterrf.org/the-foundation/research-programs/focus-area-program/Pages/waterdemand.aspx

${ }^{6}$ EPA Grant Number R836890. Right Sizing Tomorrow's Water Systems for Efficiency, Sustainability, and Public Health.

https://cfpub.epa.gov/ncer abstracts/index.cfm/fuseaction/display.abstractDetail/abstract/10736/report/2018
} 
As explained in Section E, the specific research needs and context provided by participants in the preworkshop information request responses were compiled to seed and facilitate the discussion during the workshop.

\section{E. Research Prioritization and Rationale}

The in-person Premise Plumbing Workshop was convened August 1-2, 2018, at the NIST campus in Gaithersburg, Maryland. During the workshop, participants identified, refined, and provided rationale for more than 50 potential research topics. This section contains the final, refined list of research items identified by the workgroup, as well as the rationale for each research topic, the workgroup's decision regarding relative priority among the research items, and notes on related research, if applicable. For initial discussions, the topics were organized under three overarching research categories:

- Research Area 1: Water usage patterns and end uses in commercial and residential buildings as they relate to system design and pipe sizing

- Research Area 2: Impact of piping material, design, and installation on the long-term condition of the plumbing system (potable and waste)

- Research Area 3: Impacts of water use/flow rate/water velocity/residence time on water quality, biofilm, and scale growth

During the meeting, workgroup participants discussed the high level of overlap among these three topic areas. For this reason, research items in Table 1 below are organized in order of relative overall priority, rather than relative priority within each research area. A rationale for each research item is also summarized, based on participant comments, and is written to reflect the phrasing of the comment. 
Table 1. Prioritized Research Topics From Workshop Discussion

\begin{tabular}{|c|c|c|c|}
\hline & Research Topic Description & Rationale & $\begin{array}{l}\text { Related } \\
\text { Research }\end{array}$ \\
\hline 1 & $\begin{array}{l}\text { Water quality: How do materials impact water quality } \\
\text { (biological and chemical) over the typical lifetime of the } \\
\text { plumbing system? (In other words, does material selection } \\
\text { and quality impact water quality of the premise plumbing?) } \\
\text { Do the age, condition, and type (e.g., materials, fixtures) } \\
\text { impact the growth and persistence of OPPPs (inactivation)? } \\
\text { Biological and chemical impacts are considered holistically } \\
\text { with the recognition that they can be researched } \\
\text { independently. }\end{array}$ & This is a fundamental, all-inclusive research topic. & $\begin{array}{c}\text { Related to } \\
\text { topic \#3, } \\
\# 5 \text {, \#10, } \\
\# 14\end{array}$ \\
\hline 2 & $\begin{array}{l}\text { Need data to better understand occupant behavior and } \\
\text { water usage patterns for different residential and commercial } \\
\text { building types (sequence research based on primary-use } \\
\text { types and building types with vulnerable populations [e.g., } \\
\text { hospitals, healthcare, daycare, and senior living]). }\end{array}$ & $\begin{array}{l}\text { This is a foundational piece for establishing data, } \\
\text { without which mistakes will be made. The success of } \\
\text { other research items is highly dependent on this item. } \\
\text { Current data are not consistent enough to allow } \\
\text { comparability across buildings. Addressing this need } \\
\text { provides a basis for understanding water turnover and } \\
\text { efficiency factors at reduced construction cost. The } \\
\text { research scope should not be limited to building } \\
\text { structures and can include campuses (any point after } \\
\text { main meter). Information can be used to reduce supply, } \\
\text { sewer, and branch pipe sizing. Collect data at all spatial } \\
\text { and temporal scales. Current data are lacking to inform } \\
\text { new water demand models and improve codes. Other } \\
\text { research needs and model development are dependent } \\
\text { on progress in this area. } \\
\text { Possible subtopic: How can new construction be used as } \\
\text { part of data gathering (installing devices to help monitor } \\
\text { water use/demands)? }\end{array}$ & \\
\hline
\end{tabular}




\begin{tabular}{|c|c|c|c|}
\hline & Research Topic Description & Rationale & $\begin{array}{l}\text { Related } \\
\text { Research }\end{array}$ \\
\hline 3 & $\begin{array}{l}\text { Hunter's curve needs updating, or alternatives to Hunter's } \\
\text { Curve need development (IPC/UPC needs to reflect current } \\
\text { and future trends in terms of low flows). Alternative sizing } \\
\text { models (Water Demand Calculator) need to be validated and } \\
\text { potentially improved to establish minimum and maximum } \\
\text { pipe sizing (based on data). }\end{array}$ & $\begin{array}{l}\text { Once data are collected and a new methodology is } \\
\text { established, this item will support code revisions that } \\
\text { will impact new building design. Codes are the primary } \\
\text { basis for designs used by engineers and contractors. By } \\
\text { evaluating the water demand calculator, it will provide a } \\
\text { shortcut to other research items. The methodology } \\
\text { used to establish Hunter's Curves considered flow rates } \\
\text { from } 80-100 \text { years ago and is also labeled for residential } \\
\text { only. } \\
\text { Possible subtopic: How do we design systems that can } \\
\text { operate effectively at both minimum and peak flows? }\end{array}$ & $\begin{array}{l}\text { Requires } \\
\text { data input } \\
\text { from } \\
\text { research } \\
\text { topic \#1. } \\
\text { Related to } \\
\quad \text { \#5 }\end{array}$ \\
\hline 4 & $\begin{array}{l}\text { How do factors (physical factors such as pressure and system } \\
\text { age and operational factors such as water age/stagnation, } \\
\text { flow rate, water velocity, and water temperature) impact } \\
\text { biofilm and scale and its impact on water quality within } \\
\text { different materials (considering factors such as growth rates, } \\
\text { type of biofilm, general biofilm characteristics, and ecology)? }\end{array}$ & $\begin{array}{l}\text { Biofilms and scale are important because they are major } \\
\text { drivers for quality problems. Biofilms and water quality } \\
\text { are not interchangeable, and this research area brings in } \\
\text { factors that evaluate how biofilms impact water quality. } \\
\text { Biofilms are always in contact with water and on the } \\
\text { premise, so they have a potentially large impact on } \\
\text { water. Biofilms harbor pathogens and protect them } \\
\text { from disinfectants, so it is critical to understand } \\
\text { biofilms. New and innovative products and conservation } \\
\text { drastically change the way our systems perform, and we } \\
\text { need to understand impacts. Because this research item } \\
\text { is difficult to study, it hasn't yet been done, but it's } \\
\text { important for the future. An important consideration is } \\
\text { the type of material of the incoming pipe and its impact } \\
\text { on water quality and pressure. }\end{array}$ & $\begin{array}{l}\text { Related to } \\
\quad \# 25\end{array}$ \\
\hline
\end{tabular}



performance of the entire premise plumbing system materials and subsequent water quality over the typical lifetime of the system? (Acknowledging difference between water quality entering the building and changes that occur in the building itself, including in-building treatment).

Develop a greater understanding of how water demand patterns impact water quality within premise plumbing systems.

How do water age, flow rate/velocity, pressure (variations), plumbing materials, source water, in-house treatment (POU, $\mathrm{POE})$, maintenance/operations, water temperature, and plumbing layout (manifold, trunk and branch, series) impact the dissipation rate of chlorine or other disinfectants?

The reverse of Priority Area 1. All-inclusive.

Usage information is critical to assess real-world impact. Laboratory outcomes must be compared with realworld outcomes to fully understand risk. This topic is fundamental. Design is unlikely to dictate behavior to people (e.g., when you use the restroom), so it is important to understand behavior and design accordingly. Design is currently based on outdated behavior patterns. There is a need to understand use patterns, not just water quality, and its impact on code. Hypothesis: Use is much smaller than thought and intermittency is higher (at least for residential, may differ in commercial). There is a need to understand if this is true and its impact.

Possible subtopic: What is the water quality at the service line versus at each outlet within the premise plumbing, and how is this impacted by usage patterns?

Residual disinfectant is a primary controller of water quality.
Related to \#3 


\begin{tabular}{|c|c|c|c|}
\hline & Research Topic Description & Rationale & $\begin{array}{l}\text { Related } \\
\text { Research }\end{array}$ \\
\hline 8 & $\begin{array}{l}\text { Effective approaches to retrofit or manage existing buildings } \\
\text { that are overdesigned for current and future flows. }\end{array}$ & $\begin{array}{l}\text { At present, significant stock of installed buildings exists } \\
\text { that is variable in condition, age, plumbing design, and } \\
\text { technology. This research topic would have a larger } \\
\text { impact than focusing on new construction. We do not } \\
\text { know what is effective and what is not, but people are } \\
\text { conducting retrofits in the pursuit of water efficiency or } \\
\text { because they have a problem. One workgroup member } \\
\text { stated that lower flows, lower velocity, and longer } \\
\text { residence time are creating problems right now, though } \\
\text { we don't have effective and validated management } \\
\text { protocols in place. This is likely to become even more } \\
\text { timely as more low-flow fixtures are installed in existing } \\
\text { buildings. }\end{array}$ & $\begin{array}{l}\text { Related to } \\
\# 3, \# 40\end{array}$ \\
\hline 9 & $\begin{array}{l}\text { Establish a common methodology or design element that } \\
\text { allows for collection of end use data (e.g., water quality, } \\
\text { temperature, flow rate, time-duration, frequency of data } \\
\text { gathering). Create standardized metrics (e.g., gallons per } \\
\text { minute [gpm], water velocity, water turnover rate). }\end{array}$ & $\begin{array}{l}\text { This is a foundational research item. To collect large, } \\
\text { usable data sets, you have to have a consistent } \\
\text { methodology that can be applied throughout different } \\
\text { studies. There exists a need for common language, } \\
\text { definitions, methodology, and practice. For data } \\
\text { standardization/classification, the workgroup suggests } \\
\text { creation of a committee to set data standards. } \\
\text { Establishing minimum requirements for a standard } \\
\text { water customer classification scheme and processes will } \\
\text { ensure uniformity in class definitions. } \\
\text { Possible subtopic: Consider actual pipe diameter and } \\
\text { how pipe diameter is impacted by corrosion and scaling. }\end{array}$ & $\begin{array}{l}\text { Related to } \\
\# 12, \# 17\end{array}$ \\
\hline
\end{tabular}




\begin{tabular}{|c|c|c|c|}
\hline & Research Topic Description & Rationale & $\begin{array}{l}\text { Related } \\
\text { Research }\end{array}$ \\
\hline 10 & $\begin{array}{l}\text { What are the design and operation influences/risks (including } \\
\text { super chlorination) associated with water-efficient premise } \\
\text { plumbing with regard to water quality and materials? Side } \\
\text { effects could include, but is not limited to, increased noise, } \\
\text { cavitation, temperature, water hammer, pressure surges } \\
\text { (into disinfection, water quality changes), increased erosion, } \\
\text { pressure drop, protective function of biofilms, and scale. }\end{array}$ & $\begin{array}{l}\text { This research item prevents unintended consequences } \\
\text { and settles the conflict of turning a water heater up or } \\
\text { down (e.g., conflict that currently exists between water } \\
\text { and energy). It explicitly considers risk and considers } \\
\text { materials' impacts on water, water's impacts on } \\
\text { materials, and operational impacts on both. }\end{array}$ & $\begin{array}{c}\text { Related to } \\
\# 5, \# 14\end{array}$ \\
\hline 11 & $\begin{array}{l}\text { Guidance for Designers: Establish guidance on design } \\
\text { parameters for residence time and best management design } \\
\text { practices to reduce overall stagnation time and residence } \\
\text { time. Conduct an economic analysis of alternative guidance } \\
\text { approaches and how that guidance would be validated. }\end{array}$ & $\begin{array}{l}\text { This appears to be the end goal-to provide safe water. } \\
\text { Guidance is important to provide, and it is much-needed } \\
\text { in the real world. There is a balancing act between } \\
\text { scalding and water quality. Information can be used by } \\
\text { practicing professionals and incoming students learning } \\
\text { how to design plumbing systems. There are green } \\
\text { buildings in which water sits in the system for weeks at } \\
\text { a time. How can we impact the design to prevent this? }\end{array}$ & $\begin{array}{c}\text { Guidance } \\
\text { may be an } \\
\text { end- } \\
\text { product }\end{array}$ \\
\hline 12 & $\begin{array}{l}\text { Impacts of alternative water use (e.g., net zero water, } \\
\text { rainwater harvesting, greywater recycling) and water reuse } \\
\text { (onsite and supplied) - as it affects plumbing design and } \\
\text { water use patterns (both drinking water and wastewater } \\
\text { design and operation). }\end{array}$ & $\begin{array}{l}\text { Alternative water uses are being codified, and there is a } \\
\text { need to quickly understand the overall impact on design } \\
\text { and use. Locales are already moving forward (e.g., } \\
\text { California) and as use of alternative water continues, } \\
\text { stagnation increases and there is an increased risk on } \\
\text { sanitation systems. There is a need to understand } \\
\text { impacts before rather than after we've already } \\
\text { implemented alternative water systems. }\end{array}$ & \\
\hline
\end{tabular}




\begin{tabular}{|c|c|c|c|}
\hline & Research Topic Description & Rationale & $\begin{array}{l}\text { Related } \\
\text { Research }\end{array}$ \\
\hline 13 & $\begin{array}{l}\text { Improve and validate (e.g., full-scale building tracer studies) } \\
\text { computer models of hydraulic behavior and water quality of } \\
\text { both hot and cold piping. }\end{array}$ & $\begin{array}{l}\text { Models need to be predictive and validated with current } \\
\text { practice. This research topic addresses lack of trust in } \\
\text { current models (currently incomplete). Full census isn't } \\
\text { possible, so there is a need for accuracy in models } \\
\text { where we do not have complete data. Working with } \\
\text { models will help identify where needs exist for } \\
\text { additional information. Models are already in use, so is } \\
\text { it important to identify which problems exist, if not to } \\
\text { also fix those problems. How can advancements in } \\
\text { hydraulic and water quality modeling influence building } \\
\text { designs and code? Do we need to develop reference } \\
\text { buildings for water (similar to those that exist for energy } \\
\text { codes)? There is also a need to establish validation } \\
\text { protocols to evaluate models. } \\
\text { Possible subtopic: Mixing at junctions, mixing within } \\
\text { pipes, temperature profiles, intermittent demands, } \\
\text { water storage, residence time (simple guide on key } \\
\text { characteristics and expected water age). }\end{array}$ & \\
\hline 14 & $\begin{array}{l}\text { Measurement science: What are standard measurement } \\
\text { techniques (currently no test or rating directory) to } \\
\text { determine performance parameters for fittings and pipes } \\
\text { (e.g., flow rate vs. pressure drop)? }\end{array}$ & $\begin{array}{l}\text { There is a need for a shared language and inclusion of } \\
\text { important definitions and parameters to prevent } \\
\text { confusion. This is a prerequisite and a fundamental } \\
\text { building block for design. }\end{array}$ & $\begin{array}{l}\text { Prerequisite } \\
\text { for many } \\
\text { other items }\end{array}$ \\
\hline
\end{tabular}




\begin{tabular}{|c|c|c|c|}
\hline & Research Topic Description & Rationale & $\begin{array}{l}\text { Related } \\
\text { Research }\end{array}$ \\
\hline 15 & $\begin{array}{l}\text { Evaluation of premise plumbing design and flushing } \\
\text { strategies and their impacts on water quality: In light of } \\
\text { flushing practices (drinking water quality and sanitary system } \\
\text { flows), what is the tradeoff with conservation objectives? }\end{array}$ & $\begin{array}{l}\text { This is not covered by other topics. These do not } \\
\text { currently exist in the draw patterns and should be } \\
\text { included where appropriate. There is a need for more } \\
\text { science behind current recommendations. More } \\
\text { flushing is better, but may be unnecessary. Policymakers } \\
\text { are changing fixture flow, and it may have negative } \\
\text { consequences, so there is a need to understand the } \\
\text { implications to the real world. It is also important to } \\
\text { consider conservation and outreach to the public in } \\
\text { implementing this research item. }\end{array}$ & 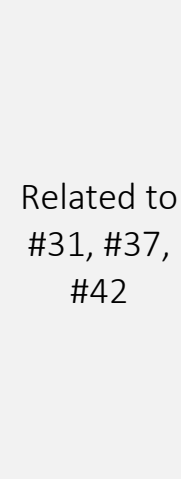 \\
\hline 16 & $\begin{array}{l}\text { Guidance for homeowners, building facility managers, and } \\
\text { practitioners: Establish guidance on operational targets for } \\
\text { maximum residence time and indicators to recognize when } \\
\text { residence time recommendations are exceeded, including } \\
\text { suggested remediation (e.g., periodic flushing, onsite } \\
\text { treatment). Conduct an economic analysis of alternative } \\
\text { guidance. }\end{array}$ & $\begin{array}{l}\text { Guidance for people interacting with their houses may } \\
\text { help them understand plumbing isn't something you can } \\
\text { ignore. This topic is so misunderstood/not thought of } \\
\text { that people think we are keeping it a secret. This needs } \\
\text { to be front-loaded. Would be important to include risk } \\
\text { perception and communication. Economic analysis is } \\
\text { important but should be balanced with conservation. At } \\
\text { present there exists a conflicting message between } \\
\text { conservation and need to flush. }\end{array}$ & $\begin{array}{l}\text { Guidance } \\
\text { may be an } \\
\text { end- } \\
\text { product }\end{array}$ \\
\hline 17 & $\begin{array}{l}\text { Define metrics for long-term conditions: Water quality, } \\
\text { resilience/durability, timescale (e.g., long- and short-term). }\end{array}$ & $\begin{array}{l}\text { Need for a shared language and inclusion of important } \\
\text { definitions and numeric aspects to prevent confusion. } \\
\text { This is a fundamental building block for design. May be } \\
\text { combined with Item \#1. Given the built inventory } \\
\text { conversation, there is a need to understand when that } \\
\text { inventory needs to be replaced. This research item is } \\
\text { tactical, foundational, and necessary to consider before } \\
\text { other research areas. }\end{array}$ & \\
\hline
\end{tabular}


Compile (i.e., obtain, screen, and archive) a national database of accurate, high-resolution water demand data from a wide variety of building types and end uses (e.g., residential, commercial, institutional, medical). Include context of where the data was collected (e.g., building type, location, age, occupancy).

Influence of newer and more complex technology on design and/or management issues (e.g., mixing valves, hot water heaters, recirculation systems).

Data and test procedure on pressure drop and performance on modern plumbing fittings (e.g., pressure-compensating fittings, various joining techniques) at different temperatures.
In order to understand/compare performance, there is a need to have a national, accessible, and consistently compiled database. This is foundational for beginning to understand usage patterns and furthering other research items. Usage factors should be kept current over time (e.g., California data collaborative).

Design should be for effectiveness rather than complexity. When flows are low, dynamics are changing, but the full impact of that change is unknown.

Manufacturers are trying to respond without research.

If this isn't done correctly, as we move towards rightsizing systems, there is potential for error and errors embedded in data will manifest more clearly. There is a need to provide correct engineering, and this is indicative of the need to question underlying numbers for design. There is a need to review numbers in light of current materials and methods, and this research topic would feed into Hunter's curve. 


\begin{tabular}{|c|c|c|c|}
\hline & Research Topic Description & Rationale & $\begin{array}{l}\text { Related } \\
\text { Research }\end{array}$ \\
\hline 21 & $\begin{array}{l}\text { Wastewater/sanitary side: How do changes to premise } \\
\text { plumbing design, incorporation of onsite reuse, reducing flow } \\
\text { rate, etc., impact the wastewater system design (and the } \\
\text { sanitary sewer system)? }\end{array}$ & $\begin{array}{l}\text { There are existing problems in plumbing systems due to } \\
\text { water flow reductions in the sanitary system (e.g., } \\
\text { fixtures and appliances) and compliance with codes. } \\
\text { Studies need to consider whether reducing the } \\
\text { building's drainage system pipe size would result in } \\
\text { better flow under lower flows and minimize corrosion. } \\
\text { At present, drainage systems are turning into septic } \\
\text { systems due to the longer residence times for waste. } \\
\text { Changes in concentration of wastewater have impacts } \\
\text { on materials. The Plumbing Efficiency Research Coalition } \\
\text { (PERC) studies on drainline carry already exist to assess } \\
\text { some commercial buildings with longer drainlines. } \\
\text { Possible subtopics: } \\
\text { What is the minimum flow rate required in a drainage } \\
\text { system to move solids and ensure flow? } \\
\text { How do we design systems that can operate effectively } \\
\text { at both minimum and peak flows? } \\
\text { Development of a definition for "low flow" (federal vs. } \\
\text { states such as California). }\end{array}$ & \\
\hline 22 & $\begin{array}{l}\text { Develop understanding of the interplay between building } \\
\text { design/architecture and plumbing system } \\
\text { design/performance. }\end{array}$ & $\begin{array}{l}\text { New construction and one-time opportunities to } \\
\text { address issues at low cost are an underrated aspect of } \\
\text { building water quality and may have practical solutions. } \\
\text { This research item looks towards the future-how we } \\
\text { design new construction. Is there a good way to } \\
\text { influence people who are coming up in design and } \\
\text { architecture-educating the next wave of the water } \\
\text { efficiency workforce to give a common goal? }\end{array}$ & \\
\hline
\end{tabular}




\begin{tabular}{|c|c|c|c|}
\hline & Research Topic Description & Rationale & $\begin{array}{l}\text { Related } \\
\text { Research }\end{array}$ \\
\hline 23 & $\begin{array}{l}\text { Investigate hydrodynamic flow regimes and transport, which } \\
\text { are prevalent in premise plumbing. }\end{array}$ & $\begin{array}{l}\text { Hydrodynamics is not completely understood. This } \\
\text { would act in support of thermodynamic modelling. } \\
\text { Consider material impacts as well. Water quality is } \\
\text { complicated to model. To create greater holistic } \\
\text { understanding, there is a need to understand } \\
\text { hydrodynamics. Since building water demands may be } \\
\text { low, we may observe laminar instead of turbulent flow. } \\
\text { Laminar flow is distinct from dispersive flow. Transport } \\
\text { includes biota, etc. }\end{array}$ & $\begin{array}{l}\text { Related to } \\
\quad \# 25\end{array}$ \\
\hline 24 & $\begin{array}{l}\text { What are the impacts of new technologies, materials, and } \\
\text { water quality (upstream, in the premise side) on wastewater } \\
\text { systems (including septic and public collection systems)? }\end{array}$ & $\begin{array}{l}\text { New and innovative products have been developed, but } \\
\text { we need a full understanding of their impacts. Already } \\
\text { experiencing issues in the field. } \\
\text { Possible subtopic: What is the impact of acidic } \\
\text { condensate or effluents from high efficiency water } \\
\text { heaters, etc.? }\end{array}$ & \\
\hline 25 & $\begin{array}{l}\text { How does water velocity impact biofilm and scale growth and } \\
\text { detachment? }\end{array}$ & $\begin{array}{l}\text { It is an important to understand biofilm and scale } \\
\text { related to the movement of water and related water } \\
\text { quality impacts. }\end{array}$ & $\begin{array}{l}\text { Related to } \\
\# 4, \# 23\end{array}$ \\
\hline 26 & $\begin{array}{l}\text { Research on temperature profiles (both spatial and temporal) } \\
\text { to guide temperature settings for water heaters (outflow } \\
\text { curves, within water heater, and in the hot water distribution } \\
\text { system). }\end{array}$ & $\begin{array}{l}\text { We potentially could provide actionable knowledge for } \\
\text { guidance, if we were able to establish a better } \\
\text { understanding. High temperature water is a critical line } \\
\text { of defense if and when loss of residual disinfection } \\
\text { occurs. A lot of goals are temperature-dependent. This } \\
\text { research topic helps verify thermodynamic modelling of } \\
\text { the plumbing systems. There are energy efficiency } \\
\text { objectives driving temperatures one way; there is a } \\
\text { need to better understand the balance between energy } \\
\text { efficiency and water quality objectives. This research } \\
\text { topic could impact how water heaters are designed. }\end{array}$ & \\
\hline
\end{tabular}


Impacts of and requirements for cold and hot water recirculation systems (including hot water to cold water returns) and temperature maintenance on water quality.

How to objectively measure/quantify impact of codes and standards on premise plumbing water quality?

Installation: What are the impacts of improper installation on water quality and system performance? How can we impact installation based on that information?

Measurement science objective: Capturing a way to describe the chemical and biological stability of influent water using select parameters.
Water temperature is strongly related to water quality (pathogen regrowth). These types of systems are more frequent and being mandated in some areas, and we need to better understand the impact on water quality and how to manage the systems to control for water quality impacts.

Codes and standards are the basic, minimum requirement, and it is critical to understand how current approaches may have side effects or unintended consequences.

Possible subtopics: To what degree are codes being enforced? How does enforcement differ regionally? What version of the code should be compared?

Installation impacts system performance. An understanding of installation variability will provide a basis to better promote effective practices to ultimately have positive impacts on system performance and water quality.

This item provides a starting point to mitigate risk. Influent water quality/conditions affect all aspects of the premise plumbing system and the appropriateness of system management approaches. Understanding influent water stability can better inform what effective system management practices will be. It is unclear, however, which metrics would be used for prediction, in part given the variability of influent water conditions. There are some metrics for stability that can act as a starting point.
Related to

Related to

$\# 1$, \#5, \#10, $\# 28$

Related to

\#4, \#7 


\begin{tabular}{|c|c|c|c|}
\hline & Research Topic Description & Rationale & $\begin{array}{l}\text { Related } \\
\text { Research }\end{array}$ \\
\hline 31 & $\begin{array}{l}\text { Impact of combined hydronic/potable systems (stagnancy, } \\
\text { time spent circulating in heating system, biofilm and scale } \\
\text { growth in water pathway) on water quality. }\end{array}$ & $\begin{array}{l}\text { Combined systems are theoretically breeding grounds } \\
\text { for pathogens, and there has been a lack of attention on } \\
\text { symptoms up to now. } \\
\text { Possible subtopic: Efficacy and best management } \\
\text { practices of exercising methodologies and intermittent } \\
\text { cycling (e.g., hydronic air handlers). }\end{array}$ & $\begin{array}{l}\text { Related to } \\
\quad \# 13\end{array}$ \\
\hline 32 & $\begin{array}{l}\text { How do the changes in occupancy and use impact the } \\
\text { efficacy of the existing premise plumbing? }\end{array}$ & $\begin{array}{l}\text { Buildings are always going to have changes in use and } \\
\text { occupancy, and we need to understand impacts on } \\
\text { efficacy. }\end{array}$ & \\
\hline 33 & $\begin{array}{l}\text { Water heater type and operation and related influence on } \\
\text { water quality. }\end{array}$ & $\begin{array}{l}\text { All occupied buildings have a water heater, and } \\
\text { temperature is an overarching consideration. Better } \\
\text { understanding can help with existing and new buildings' } \\
\text { fuel type, capacity, and mixing characteristics. Thorough } \\
\text { assessment of water heater performance with regards } \\
\text { to pathogens would fill a huge gap. Different water } \\
\text { heaters perform differently with regard to temperature. } \\
\text { Efficient heaters perform differently with regard to } \\
\text { pathogen growth. There is current, large societal } \\
\text { investment (tax credits) to promote efficient heaters } \\
\text { without information on their impact on pathogens. } \\
\text { Possible subtopic: Net-zero carbon and water heaters as } \\
\text { storage. }\end{array}$ & \\
\hline 34 & $\begin{array}{l}\text { Influence of dead-ends/dead-legs (either from incomplete } \\
\text { renovations or roughed in for future plumbing) on water } \\
\text { flow, age, and quality. }\end{array}$ & $\begin{array}{l}\text { Dead-ends exist in every building, and if there is a } \\
\text { detriment it should be understood. Dead-ends are } \\
\text { inevitable, yet unresearched. How are dead-ends } \\
\text { established (for future expansion vs. by incomplete } \\
\text { renovations)? }\end{array}$ & \\
\hline
\end{tabular}




\begin{tabular}{|c|c|c|c|}
\hline & Research Topic Description & Rationale & $\begin{array}{l}\text { Related } \\
\text { Research }\end{array}$ \\
\hline 35 & $\begin{array}{l}\text { Water quality and scaling impacts on pressure drop, material } \\
\text { selection, design, etc. }\end{array}$ & $\begin{array}{l}\text { Scaling plays a complex role in the plumbing system } \\
\text { (reduces heat exchanger performance, degrades pipes, } \\
\text { integral to water quality) and yet requires additional } \\
\text { research, as it is not well understood. For example, } \\
\text { scaling may increase pathogens, but protect against } \\
\text { lead (i.e., scaling helps prevent erosion, corrosion). }\end{array}$ & \\
\hline 36 & $\begin{array}{l}\text { Investigating international approaches to design and } \\
\text { treatment that reduce reliance on disinfection (with regards } \\
\text { to the utility and premise). }\end{array}$ & $\begin{array}{l}\text { This item is ow-hanging fruit. We are stuck in a chlorine- } \\
\text { residual bubble and need to consider other alternatives. } \\
\text { The research is already complete. }\end{array}$ & $\begin{array}{l}\text { Related to } \\
\quad \# 1\end{array}$ \\
\hline 37 & $\begin{array}{l}\text { Establish emergency fixtures (i.e., eye wash stations, } \\
\text { emergency showers) best management practices (e.g., } \\
\text { flushing) as required by manufacturers/standards. }\end{array}$ & $\begin{array}{l}\text { We have long runs of hot and cold water piping to } \\
\text { provide tepid water to emergency fixtures. } \\
\text { Requirements are based on assumptions not on fact, } \\
\text { and we should develop requirements based on facts. } \\
\text { (Note: Emergency fixtures do not include fire } \\
\text { sprinklers.) } \\
\text { Possible subtopic: Manufacturers currently set } \\
\text { requirements for flushing-are they sufficient? } \\
\text { Excessive? Not going far enough? }\end{array}$ & \\
\hline 38 & $\begin{array}{l}\text { Investigate opportunities to foster competitive or "beneficial" } \\
\text { biofilms and scale, including designing biofilm communities } \\
\text { to improve water quality. }\end{array}$ & $\begin{array}{l}\text { Biofilm is inevitable, and understanding how to } \\
\text { encourage good growth is important. It's a future item, } \\
\text { but it's never too early to start on the future. }\end{array}$ & \\
\hline 39 & $\begin{array}{l}\text { Investigate current construction best practices for } \\
\text { recirculation lines and temperature maintenance systems } \\
\text { (e.g., mitigate biofilm and scale buildup) with the intention of } \\
\text { improving them in the future, with water quality, energy, and } \\
\text { erosion/corrosion/scale as investigative endpoints. }\end{array}$ & $\begin{array}{l}\text { Many of these systems exist, and not much is known } \\
\text { about how they impact water quality. Controls and } \\
\text { strategies will be different on simple and complex } \\
\text { systems. }\end{array}$ & $\begin{array}{l}\text { Related to } \\
\quad \# 27\end{array}$ \\
\hline
\end{tabular}




\begin{tabular}{|c|c|c|c|}
\hline & Research Topic Description & Rationale & $\begin{array}{c}\text { Related } \\
\text { Research }\end{array}$ \\
\hline 40 & $\begin{array}{l}\text { Establish a protocol to identify plumbing design of existing } \\
\text { buildings. }\end{array}$ & $\begin{array}{l}\text { We have limited understanding of existing building } \\
\text { premise plumbing system characteristics. This leaves a } \\
\text { gap relative to formulating renovation and management } \\
\text { practice recommendations for proper system operation. }\end{array}$ & $\begin{array}{l}\text { Related to } \\
\quad \# 8\end{array}$ \\
\hline 41 & $\begin{array}{l}\text { Resolving ongoing research regarding pipe diameter as it } \\
\text { influences biofilm and scale growth, which may depend on } \\
\text { variations in surface area contact inside pipe. }\end{array}$ & $\begin{array}{l}\text { Practice is trending towards smaller diameter pipes. } \\
\text { New information is indicating that it may be problematic } \\
\text { from a microbiological standpoint, and there is a need } \\
\text { to understand this quickly. An important aspect is the } \\
\text { influence of pipe diameter on flow regime and the } \\
\text { related influence on biofilm growth and detachment. }\end{array}$ & \\
\hline 42 & $\begin{array}{l}\text { Impact of multipurpose residential piping or limited area } \\
\text { sprinkler systems on water quality. }\end{array}$ & $\begin{array}{l}\text { Systems can or may have substantial amounts of } \\
\text { stagnant water at one temperature, and that has the } \\
\text { potential to act as a breeding ground for pathogens. } \\
\text { Requirements for fire sprinklers are adopted in state } \\
\text { code for residential structures. }\end{array}$ & \\
\hline 43 & $\begin{array}{l}\text { Establish standard classifications and sub-classifications for } \\
\text { multifamily and commercial, institutional, and industrial (CII) } \\
\text { building types (consider existing census and DOE } \\
\text { classifications) to support collection of consistent information } \\
\text { conducive to capture in a centralized database. }\end{array}$ & $\begin{array}{l}\text { [Rationale not discussed during workshop due to time } \\
\text { constraints.] }\end{array}$ & \\
\hline 44 & $\begin{array}{l}\text { Develop methods to apply existing data sets on water end- } \\
\text { use accounting to similar building types (e.g., multifamily and } \\
\text { Cll subcategories). For example, can information from } \\
\text { Residential End Uses of Water be applied to the multifamily } \\
\text { sector? }\end{array}$ & $\begin{array}{l}\text { [Rationale not discussed during workshop due to time } \\
\text { constraints.] }\end{array}$ & \\
\hline 45 & $\begin{array}{l}\text { Information to improve plumbing and sewer modeling to be } \\
\text { used with BIM (building information modeling) platforms. }\end{array}$ & $\begin{array}{l}\text { [Rationale not discussed during workshop due to time } \\
\text { constraints.] }\end{array}$ & \\
\hline
\end{tabular}




\begin{tabular}{|c|c|c|c|}
\hline & Research Topic Description & Rationale & $\begin{array}{l}\text { Related } \\
\text { Research }\end{array}$ \\
\hline 46 & Run-out length and diameter related to end-use flow rates. & $\begin{array}{l}\text { [Rationale not discussed during workshop due to time } \\
\text { constraints.] }\end{array}$ & \\
\hline 47 & $\begin{array}{l}\text { Material compatibility: How does the use of mixed materials } \\
\text { in a system (material compatibility) impact water quality and } \\
\text { the integrity of the system? }\end{array}$ & $\begin{array}{l}\text { [Rationale not discussed during workshop due to time } \\
\text { constraints.] }\end{array}$ & \\
\hline 48 & What is the impact of electrical grounding to pipes? & $\begin{array}{l}\text { [Rationale not discussed during workshop due to time } \\
\text { constraints.] }\end{array}$ & \\
\hline
\end{tabular}




\section{F. Final Observations From the Workshop}

At the conclusion of the two-day workshop, participants provided their observations of the session and identified any gaps still remaining in research needs for premise plumbing.

Workshop participants identified three overarching categories that encompassed several of the research topics and could serve as the foundation for the resulting research roadmap:

Water Use Data (Research Topics 2, 6, 12, 18, 32, 44, 45, and 46)

Workshop participants saw a need for additional data on how water is being used in different types of residential and commercial buildings. There is a need for national, accessible, and consistently compiled databases that can provide a foundation for research efforts. In addition to data that reflect the types of uses and/or fixtures, it is also important to have more data on how occupant behavior influences water use.

New Ways of Thinking About Design (Research Topics 3, 11, 19, 21, and 48)

There was agreement that the models that influence plumbing system designs need be updated to reflect present-day water demand patterns and the integration of newer, more complex technology into the built environment. Designers, practicing professionals, and incoming students also need guidance to help them maintain existing and design new plumbing systems.

Understanding Changes in Input Water Quality in Premise Plumbing to Determine Starting Point (Research Topics 1, 3, 5, 6, 7, 22, 35, 36, and 42)

Workshop participants agreed that there needs to be a better understanding of the interactions between water quality and premise plumbing. There is a need for more integrated and interdisciplinary projects that consider the influence of water quality on premise plumbing materials and vice versa and how design or water use patterns influence biological and chemical quality of water.

The group also identified a number of themes that reflect cross-cutting recommendations across research items.

\section{Standardization}

Workgroup participants noted that several of the identified research topics focused on the need for standard definitions to create a shared understanding and common language. There also needs to be a standard protocol for measuring, reporting and archiving water use (demand) readings taken at all types of premise plumbing systems. Participants also advocated for widening the lens from single-family homes to include large and complex building systems. Workgroup participants indicated that research topics related to standardization were fundamental, without which the research agenda would fail to achieve its intended impact.

\section{Existing Data}

Workshop participants stressed that there is currently a fair amount of data that should be used to shortcut or accelerate some of the identified research topics. Specifically, participants noted that residential data are available, while data in other sectors, such as commercial, may not be available at present. 


\section{Sequential Research Needs}

Workshop participants discussed the different types of end products across research topics. For some research topics, such as Topics 11 and 16, the end product may be a guidance document, and these types of products may need to be sequenced after research into best practices has been completed.

Finally, the group had several high-order reflections that should be taken into consideration as the roadmap is developed and research projects are carried out.

\section{Holistic Approach}

Workshop participants stressed the need for a holistic, multivariable approach with long-term analysis of real systems. Participants noted that the top priorities were all holistic in nature. Though this approach may bring increased complexity and difficulty, participants reinforced their desire for any research agenda to prioritize a commitment to a comprehensive approach.

\section{Risk and Recommendation Communications}

Workshop participants stressed that most of the research items identified above will require significant changes to water sector professional and end-user behavior. As such, research and guidance should be layered with risk communication research and recommendation development.

\section{Impact to Disadvantaged Communities}

Workshop participants recommended that any research package include a discussion of impacts to disadvantaged communities and a roadmap for lessening impact to those communities. Participants noted that it will be difficult to understand impacts until the above research determines an appropriate path forward.

\section{Industry Communication}

Workshop participants noted that there is currently a gap in communication among the water treatment sector, homeowners and building operators, and plumbing professionals. Participants identified a need for communications among these groups and an identification of roles with respect to treatment and regulation.

\section{The Cost of Inaction}

Workshop participants discussed the need to understand the full cost of inaction and not conducting remediation. Once the cost impact of inaction is better understood, it would be a very useful tool to persuade stakeholders of the need for cooperation and action.

\section{Definition of Water Quality}

Throughout the workshop, participants discussed the need to define water quality to create a shared understanding, while noting that water quality can mean vastly different things when water is in the distribution network as compared to when it enters premise plumbing. 


\section{G. Future Work}

The feedback from the workshop participants will be helpful to the steering committee as they work to develop research plans for premise plumbing and may also prove useful to organizations working on premise plumbing issues. The EPA and WRF will continue to address research needs in this important strategic area. NIST intends to build upon the information obtained from this workshop and release a research roadmap that also considers input from a broader community and range of topics. This research roadmap is intended to be used by a variety of stakeholders for planning and coordination of research needed to improve the state of the industry. As part of NIST's effort to gather more information, NIST issued a Request for Information (RFI) in October 2018 to solicit additional feedback on issues for which further

research would help ensure the design and operation of healthy, safe, and efficient plumbing systems. ${ }^{7}$ NIST anticipates releasing this research roadmap in the first half of 2019. Project updates can be found at www.nist.gov/programs-projects/water-use-high-performance-buildings.

\footnotetext{
${ }^{7}$ NIST's RFI can be reviewed at www.nist.gov/el/energy-and-environment-division-73200/rfi-response
} 


\section{Appendix A: Premise Plumbing Workshop Agenda, August 1-2, 2018}




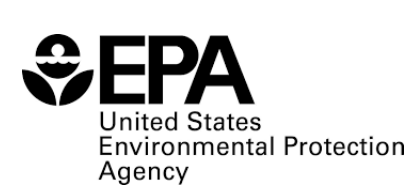

Environmental Protection Agency
NIT

National Institute of

Standards and Technology
THE

Water

Research

FOUNDATION

\section{Premise Plumbing Workshop}

\section{August 1-2, 2018}

Meeting Objectives:

- Refine and Complete the List of Individual Research Items

- Articulate the Intended Purpose and Rationale for Proposed Research Items

- Reveal and Understand Preferences for High Priority Research Items

- Establish Degree of Natural Convergence Among Workgroup Participants for High Priority Research Items

- Provide a Strong Basis for Identifying Research Topics Needed to Inform Future Code Revisions and Any Challenges to Pursue Those Topics

\section{Day 1: Agenda}

\begin{tabular}{|c|c|}
\hline $8: 30$ & $\begin{array}{l}\text { Welcoming Remarks from NIST Leadership } \\
\text { - Howard Harary, Engineering Laboratory Director }\end{array}$ \\
\hline $8: 35$ & $\begin{array}{l}\text { Opening remarks from co-sponsors } \\
\text { - } \quad \text { Andrew Persily, NIST } \\
\text { - } \quad \text { Veronica Blette, EPA } \\
\text { - } \quad \text { Beate Wright, WRF } \\
\end{array}$ \\
\hline $8: 45$ & $\begin{array}{l}\text { Review Workshop Goals \& Agenda } \\
\text { - } \quad \text { David Yashar, NIST } \\
\text { - } \quad \text { Rob Greenwood, Ross Strategic }\end{array}$ \\
\hline 9:00 & $\begin{array}{l}\text { Review of Input Received Prior to Workshop } \\
\text { - } \quad \text { Robbie Pickering, ERG }\end{array}$ \\
\hline $9: 15$ & $\begin{array}{l}\text { Overview of related research activity led by EPA and WRF } \\
\text { - } \quad \text { Veronica Blette, EPA } \\
\text { - } \quad \text { Maureen Hodgins, WRF }\end{array}$ \\
\hline $9: 40$ & $\begin{array}{l}\text { Group Brainstorm } \\
\text { - Are there any gaps or needed additions in the input received prior to the workshop? }\end{array}$ \\
\hline $10: 30$ & Break \\
\hline $10: 45$ & $\begin{array}{l}\text { Session 1a: Parallel Breakout } \\
\text { - Research Area 1: Water usage patterns and end uses in commercial and residential buildings as it relates } \\
\text { to system design and pipe sizing } \\
\text { - Research Area 2: Impact of piping material and installation on the long-term condition of the plumbing } \\
\text { system }\end{array}$ \\
\hline
\end{tabular}


Breakout Discussion:

- What additions, refinements, or clarifications are needed to the listed research items?

- What is the context for each individual research item?

- Is this a short-term or long-term research item, and is it applicable to new/existing construction or both?

\begin{tabular}{|c|c|}
\hline $12: 00$ & Lunch \\
\hline 1:00 & $\begin{array}{l}\text { Session } \mathbf{1 b} \text { : Full Plenary Report Out } \\
\text { - } \quad \text { Report Out } \\
\text { - } \quad \text { Refinements and Additions } \\
\end{array}$ \\
\hline $1: 30$ & $\begin{array}{l}\text { Session 2a: Parallel Breakout } \\
\text { - Research Area 1: Water usage patterns and end uses in commercial and residential buildings as it relates } \\
\text { - to system design and pipe sizing (Review of Session } 1 \text { and Further Refinement) } \\
\text { Breakout Discussion: } \\
\text { - What additions, refinements, or clarifications are needed to the listed research items? } \\
\text { - What is the context for each individual research item? } \\
\text { - Is this a short-term or long-term research item, and is it applicable to new/existing construction or both? }\end{array}$ \\
\hline 3:00 & $\begin{array}{l}\text { Session } \mathbf{2 b} \text { : Full Plenary Report Out } \\
\text { - } \quad \text { Report Out } \\
\text { - } \quad \text { Refinements and Additions } \\
\end{array}$ \\
\hline $3: 30$ & Initial Discussion of Research Priorities \\
\hline 4:45 & Adjourn \\
\hline $6: 00$ & “No Host” Dinner @ DogFish Head Alehouse \\
\hline
\end{tabular}

\section{Day 2 Agenda}

\begin{tabular}{l|l}
$8: 30$ & $\begin{array}{l}\text { Recap of Day } \mathbf{1} \\
\text { Group Discussion } \\
\end{array}$ \\
& $\begin{array}{l}\text { Research Priorities (dependencies, short term vs. long term) } \\
\text { Break }\end{array}$ \\
\hline $10: 30$ & Summary, Recommendations, and Next Steps \\
\hline $11: 00$ & Farewell Lunch
\end{tabular}

For those that wish to participate:

\begin{tabular}{l|l}
$1: 15$ & $\begin{array}{l}\text { Brief Review of Plumbing Tower History \& Tour, Net-Zero House } \\
\quad \text { Report Out }\end{array}$ \\
\hline $2: 15$ & $\begin{array}{l}\text { Group Brainstorm Session on Facility Requirements to Address Measurement Science } \\
\text { Needs }\end{array}$ \\
\hline $3: 45$ & Adjourn \\
\hline
\end{tabular}


Appendix B: Premise Plumbing Workshop Attendees 


\begin{tabular}{|c|c|c|c|}
\hline Name & Title & Stakeholder Area & Organization \\
\hline Peter DeMarco & $\begin{array}{l}\text { Executive Vice } \\
\text { President of Advocacy } \\
\text { and Research }\end{array}$ & Standards/Codes/Rating & $\begin{array}{l}\text { International } \\
\text { Association of } \\
\text { Plumbing and } \\
\text { Mechanical Officials } \\
\text { (IAPMO) }\end{array}$ \\
\hline Marc Edwards & $\begin{array}{l}\text { University } \\
\text { Distinguished } \\
\text { Professor of Civil } \\
\text { Engineering }\end{array}$ & Academia & $\begin{array}{l}\text { Virginia Polytechnic } \\
\text { Institute and State } \\
\text { University (Virginia } \\
\text { Tech) }\end{array}$ \\
\hline Fernando Fernandez & $\begin{array}{l}\text { Director of Codes and } \\
\text { Standards }\end{array}$ & Trade Association & $\begin{array}{l}\text { Plumbing } \\
\text { Manufacturers } \\
\text { International; TOTO } \\
\text { USA }\end{array}$ \\
\hline Kathryn Foster & $\begin{array}{l}\text { Technical Operations } \\
\text { Manager for Water } \\
\text { Distribution Systems }\end{array}$ & Standards/Codes/Rating & $\begin{array}{l}\text { National Sanitation } \\
\text { Foundation (NSF) } \\
\text { International }\end{array}$ \\
\hline Rob Greenwood & Principal & Contractor & Ross Strategic \\
\hline Bill Healy & $\begin{array}{l}\text { Leader of Heat } \\
\text { Transfer and } \\
\text { Alternative Energy } \\
\text { Systems Group, } \\
\text { Energy and } \\
\text { Environment Division }\end{array}$ & Federal & NIST \\
\hline Maureen Hodgins & Research Manager & $\begin{array}{l}\text { Non-profit Research } \\
\text { Organization }\end{array}$ & $\begin{array}{l}\text { Water Research } \\
\text { Foundation (WRF) }\end{array}$ \\
\hline Chris Impellitteri & $\begin{array}{l}\text { Associate National } \\
\text { Program Director, } \\
\text { Safe and Sustainable } \\
\text { Water Resources } \\
\text { Research Program }\end{array}$ & Federal & $\begin{array}{l}\text { EPA, Office of Research } \\
\text { and Development } \\
\text { (ORD) }\end{array}$ \\
\hline Paula Kehoe & $\begin{array}{l}\text { Director of Water } \\
\text { Resources }\end{array}$ & Water Utility & $\begin{array}{l}\text { San Francisco Public } \\
\text { Utilities Commission }\end{array}$ \\
\hline Jim Kendzel & $\begin{array}{l}\text { Vice President, } \\
\text { Advocacy }\end{array}$ & Trade Association & $\begin{array}{l}\text { American Supply } \\
\text { Association (ASA) }\end{array}$ \\
\hline Andy Kireta, Jr. & $\begin{array}{l}\text { Vice President, } \\
\text { Market Development }\end{array}$ & Trade Association & $\begin{array}{l}\text { Copper Development } \\
\text { Association Inc. }\end{array}$ \\
\hline Gary Klein & President & Consultant & $\begin{array}{l}\text { Gary Klein \& } \\
\text { Associates }\end{array}$ \\
\hline Oleh Kowalskyj & $\begin{array}{l}\text { Deputy Director for } \\
\text { Healthcare } \\
\text { Engineering }\end{array}$ & Federal & $\begin{array}{l}\text { Veterans Health } \\
\text { Administration (VHA) }\end{array}$ \\
\hline
\end{tabular}




\begin{tabular}{|c|c|c|c|}
\hline Name & Title & Stakeholder Area & Organization \\
\hline Juneseok Lee & $\begin{array}{l}\text { Associate Professor of } \\
\text { Civil and } \\
\text { Environmental } \\
\text { Engineering }\end{array}$ & Academia & Manhattan College \\
\hline Jim Lutz & $\begin{array}{l}\text { Independent } \\
\text { Researcher }\end{array}$ & Consultant & Hot Water Research \\
\hline Lance MacNevin & $\begin{array}{l}\text { Director of } \\
\text { Engineering }\end{array}$ & Trade Association & $\begin{array}{l}\text { Plastics Pipe Institute } \\
\text { (PPI) }\end{array}$ \\
\hline Ramiro Mata & $\begin{array}{l}\text { Senior Director of } \\
\text { Technical and } \\
\text { Regulatory Affairs }\end{array}$ & Industry & $\begin{array}{l}\text { American Society of } \\
\text { Plumbing Engineers } \\
\text { (ASPE) }\end{array}$ \\
\hline $\begin{array}{l}\text { Natascha Milesi- } \\
\text { Ferretti }\end{array}$ & $\begin{array}{l}\text { Mechanical Engineer, } \\
\text { Mechanical Systems } \\
\text { and Controls Group }\end{array}$ & Federal & NIST \\
\hline Jade Mitchell & $\begin{array}{l}\text { Associate Professor, } \\
\text { Biosystems and } \\
\text { Agricultural } \\
\text { Engineering } \\
\text { Department }\end{array}$ & Academia & $\begin{array}{l}\text { Michigan State } \\
\text { University }\end{array}$ \\
\hline Kathleen Onorevole & $\begin{array}{l}\text { Environmental } \\
\text { Scientist }\end{array}$ & Contractor & $\begin{array}{l}\text { Eastern Research } \\
\text { Group, Inc (ERG) }\end{array}$ \\
\hline Ed Osann & $\begin{array}{l}\text { Senior Water Policy } \\
\text { Analyst }\end{array}$ & $\begin{array}{l}\text { Non-profit, Water } \\
\text { Efficiency/Environmental }\end{array}$ & $\begin{array}{l}\text { Natural Resources } \\
\text { Defense Council } \\
\text { (NRDC) }\end{array}$ \\
\hline Thomas Pape & Principle & Consultant; Non-profit & $\begin{array}{l}\text { Best Management } \\
\text { Partners; Alliance for } \\
\text { Water Efficiency }\end{array}$ \\
\hline Dave Parney & $\begin{array}{l}\text { Executive Vice } \\
\text { President }\end{array}$ & Trade Association & $\begin{array}{l}\text { Cast Iron Soil Pipe } \\
\text { Institute (CISPI) }\end{array}$ \\
\hline Andrew Persily & $\begin{array}{l}\text { Chief, Energy and } \\
\text { Environment Division }\end{array}$ & Federal & NIST \\
\hline Robert Pickering & $\begin{array}{l}\text { Environmental } \\
\text { Engineer }\end{array}$ & Contractor & ERG \\
\hline Caitlin Proctor & Researcher & Academia & $\begin{array}{l}\text { Purdue University/ } \\
\text { Swiss Federal Institute } \\
\text { of Aquatic Science and } \\
\text { Technology (EAWAG) }\end{array}$ \\
\hline Jonah Schein & $\begin{array}{l}\text { Technical Coordinator } \\
\text { for Homes \& Buildings }\end{array}$ & Federal & EPA, WaterSense \\
\hline Maureen Schmelling & Supervisor & Water Utility & DC Water \\
\hline
\end{tabular}




\begin{tabular}{|c|c|c|c|}
\hline Name & Title & Stakeholder Area & Organization \\
\hline Sarah Shadid & Associate & Contractor & Ross Strategic \\
\hline Matt Sigler & Technical Director & Trade Association & $\begin{array}{l}\text { Plumbing } \\
\text { Manufacturers } \\
\text { International (PMI) }\end{array}$ \\
\hline Paul Sturman & $\begin{array}{l}\text { Industrial Coordinator } \\
\text { and Research } \\
\text { Professor, Center for } \\
\text { Biofilm Engineering }\end{array}$ & Academia & $\begin{array}{l}\text { Montana State } \\
\text { University }\end{array}$ \\
\hline Stephanie Tanner & Lead Engineer & Federal & EPA, WaterSense \\
\hline Tania Ullah & $\begin{array}{l}\text { Mechanical Engineer, } \\
\text { Energy and } \\
\text { Environment Division }\end{array}$ & Federal & NIST \\
\hline $\begin{array}{l}\text { Deborah Vacs } \\
\text { Renwick }\end{array}$ & $\begin{array}{l}\text { Environmental } \\
\text { Engineer }\end{array}$ & Federal & $\begin{array}{l}\text { EPA, Office of Ground } \\
\text { Water and Drinking } \\
\text { Water }\end{array}$ \\
\hline Beate Wright & Executive Director & $\begin{array}{l}\text { Non-profit Research } \\
\text { Organization }\end{array}$ & WRF \\
\hline David Yashar & $\begin{array}{l}\text { Deputy Chief, Energy } \\
\text { and Environment } \\
\text { Division }\end{array}$ & Federal & NIST \\
\hline
\end{tabular}


Appendix C: Premise Plumbing Workshop References 
International Code Council (ICC)

- International Green Construction Code \& WEP Water Efficiency Provisions

\section{KWR (Netherlands)}

- SIMDEUM (Simulation of Water Demand and End Use Model): https://www.kwrwater.nl/en/toolsproducten/simdeum/

- $\quad$ Review of applications of SIMDEUM, a stochastic drinking water demand model with small temporal and spatial scale (2017 paper describing uses)

Loading Units Normalisation Assessment Project, UK

- A Proposed New UK Framework for the Sizing of Domestic Hot and Cost Water Systems for MediumLarge Scale Residential Buildings (2017)

- An assessment of the validity of the loading units method for sizing domestic hot and cold water services

\section{National Academy of Sciences}

- Drinking Water Distribution Systems: Assessing and Reducing Risks (2006)

- Using Graywater and Stormwater to Enhance Local Water Supplies: An Assessment of Risks, Costs, and Benefits (2016) (also WRF 4521)

\section{National Blue Ribbon Commission for Onsite Non-potable Water Systems}

- $\quad$ An effort carried out by US Water Alliance, Water Environment and Reuse Foundation and Water Research Foundation.

- Resources

- Making the Utility Case for Onsite Non-potable Water Systems

- A Guidebook for Developing and Implementing Regulations for Onsite Non-potable Water Systems, Making the Utility Case for Onsite Non-potable Water Systems.

- Model State Regulation for Onsite Non-potable Water Programs

- Model Local Ordination for Onsite Non-potable water programs

- Model Program Rules for Onsite Non-potable Water Programs

- Technical Appendix: A Guidebook for Developing and Implementing Regulations for ONWS

- Risk Based Framework for Development of Public Health Guidance for Decentralized Non-Potable Water Systems

- Blueprint for Onsite Water Systems: Step by Step Guide for Developing a Local Program to Manage Onsite Water Systems

\section{National Institute of Building Sciences}

- 2016 Moving Forward: Findings and Recommendations from the Consultative Council - one focus for the report was water resources and the built environment

- Consultative Council Fact Sheet on: Efficient Use of Water

National Institute of Standards and Technology (NIST)

- Water Use in High-Performance Buildings

- Measurement Science Roadmap for Net-Zero Energy Buildings - provided as an example of what NIST envisions as the outcome of this effort. 


\section{NSF International}

- Legionella Conference 2018 (with National Science Foundation): Managing Legionella and Other Pathogens in Building Water Systems - note that presentations are available for viewing

- NSF 444: Prevention of Injury and Disease Associated with Building Water Systems - in development

\section{Plastic Pipe and Fittings Association (PPFA)}

- $\quad$ PPFA is a North American trade association comprised of member companies that manufacture plastic piping, fittings and solvent cements for plumbing and related applications, or supply raw materials, ingredients or machinery for the manufacturing process. PPFA's publications are found here.

\section{Plastic Pipe Institute (PPI)}

- The Building \& Construction Division focuses on pressure pipe materials used within building premises for plumbing, hydronics, fire protection and geothermal. These materials are CPVC, PE-RT, PEX, PP and HDPE. Many of PPI's publications are found here but they also have educational courses, magazine articles, and many other resources on the website, usually within two clicks of the first page. For instance, this course on PEX plumbing has many technical details about these systems.

\section{Plumbing Efficiency Research Coalition (PERC)}

- $\quad$ Drainline Transport of Solid Waste in Buildings

\section{San Francisco Public Utility Commission}

- $\quad$ Non-Potable Water System Program, including Non-potable Water Ordinance.

\section{Water Research Foundation (WRF)}

- Note: Water Environment \& Reuse Foundation and Water Research Foundation merged as of January 1,2018 , and are still creating a combined website.

- Lead and Copper

- Research Focus Area: Lead and Copper Management. Started 2017, ongoing.

- Lead and Copper Corrosion: Overview of WRF Research

- Potable Water Use

- Water Use Estimates Knowledge Area and Fact Sheet

- Research Focus Area: Water Demand: Improving the Effectiveness of Forecasts and Management, 2012 - 2018.

- Key Projects (see project list for more complete list)

- Ongoing, Project 4689: Assessing Water Demand Patterns to Improve Sizing of Water Meters and Service Lines

- 2018, Project 4554: Water Use in the Multi-Family Housing Sector (no high frequency data collection)

- 2016, Project 4309: Residential End Uses of Water, Version 2

- 2000, Project 241, Commercial and Institutional Uses of Water

- 1999, Project 241, Residential End Uses of Water

- Reuse

- Legacy WERF: 2018 Water Reuse Program including potable and non-potable reuse at utility scale and onsite. Grants include Direct Potable Research Initiative (\$2.1 M grant from California Department of Water of Resources) and 2018 State Water Resources Control Board Grant $(\$ 2.5 \mathrm{M}$ with 12 RFPs to be released in Fall 2018). 
- Legacy WRF: Potable Reuse Knowledge Area and Fact Sheet.

- Key projects (see project list for more complete list)

- To be awarded, RFP, Development of a Design, Operations and Regulations Guidance Manual and Training Materials for Onsite Non-Potable Water Systems, 4909.

- Ongoing, 4691, Building-Scale Treatment for Direct Potable Water Reuse \& Intelligent Control for Real Time Performance Monitoring

- 2017, 4632, Risk Based Framework for the Development of Public Health Guidance for Decentralized Non-potable Water Systems.

- 2014, 4580, Blueprint for Onsite Water Systems: A Step-by-Step Guide for Developing a Local Program to Manage Onsite Water Systems.

- Waterborne Pathogens in Premise Plumbing

- Research Focus Area: Emerging Waterborne Pathogens in Distribution Systems and Premise Plumbing. Ongoing. Developed 8 projects. Have funded 4.

- Key projects (see project list for more complete list)

- 2016, Project 4606: Research Plan for Management of Emerging Pathogens Associated with Distribution Systems.

- 2015, Project 4383: Green Building Design: Water Quality Considerations

- 2013, Project 4379: State of the Science and Research Needs for Opportunistic Pathogens in Premise Plumbing

World Health Organization and World Plumbing Council

- 2006. Health aspects of plumbing. 